\title{
A 4-component sex pheromone of the Chilean fruit leaf roller Proeulia auraria (Lepidoptera: Tortricidae)
}

\author{
Luis Reyes-Garcia ${ }^{1}$, Yuri Cuevas², Carolina Ballesteros², Tomislav \\ Curkovic $^{2}$, Christer Löfstedt ${ }^{3}$, and Jan Bergmann ${ }^{1}$ \\ 'Instituto de Química, Pontificia Universidad Católica de Valparaíso. Avda. Universidad 330, Curauma, \\ Valparaíso, Chile. \\ ${ }^{2}$ Facultad de Ciencias Agronómicas, Universidad de Chile. Casilla 1007, Santiago, Chile. \\ ${ }^{3}$ Department of Biology, University of Lund. Box 117, 22100 Lund, Sweden.
}

\begin{abstract}
L. Reyes-Garcia, Y. Cuevas, C. Ballesteros, T. Curkovic, C. Löfstedt, and J. Bergmann. 2014. A 4-component sex pheromone of the Chilean fruit leaf roller Proeulia auraria (Lepidoptera: Tortricidae). Cien. Inv. Agr. 41(2):187-196. The Chilean fruit leaf roller Proeulia auraria is a pest of economically important fruit species. Two compounds attractive to males have been identified as (E)-11-tetradecenyl acetate (E11-14:OAc) and (E)-11tetradecenol (E11-14:OH) and are currently being used in Chile to monitor this species. Preliminary experiments carried out by our group suggested that the 2-compound mixture might not be optimal for the attraction of males, which prompted us to reinvestigate the sex pheromone of P. auraria in the present study. The pheromone component candidates were extracted from pheromone glands with hexane and identified by gas chromatography (GC) with electroantennographic detection (EAD), GC-mass spectrometry, and a comparison of the analytical data of the natural compounds with those of authentic reference substances. The EAD active compounds were identified as tetradecyl acetate (14:OAc), E11-14:OAc, (Z)-11-tetradecenyl acetate (Z11-14:OAc), and E11-14:OH in a relative ratio of 11:100:4:37, respectively. Field tests showed that all four compounds are behaviorally active. The most attractive blend, which is more attractive than the 2-component mixture that is currently in use, contained the main compound E11-14:OAc, 1\% of the geometric isomer Z11-14:OAc, and both of the other minor compounds. Increasing the relative amount of Z11-14:OAc to $4 \%$ of the major component resulted in a significant reduction of attraction. An analysis of the fatty acid content of the pheromone gland revealed the presence of $(E)$-11-tetradecenoate but not of $(Z)$ 11 -tetradecenoate. The possible role in species isolation and the possible biosynthetic origin of this strongly E-biased pheromone are discussed.
\end{abstract}

Key words: Eulia, Euliini, native species, sex attractant, Tortricinae.

\section{Introduction}

The Chilean fruit leaf roller Proeulia auraria Clarke (Lepidoptera: Tortricidae) is a polypha-

Received December 27, 2013. Accepted April 1, 2014. Corresponding author: jan.bergmann@ucv.cl gous insect that is native to Chile. This species is distributed mainly in the central-southern region, and its host plants include economically important species, such as stone and pip fruit trees, grapes, citrus, blueberries, and other crops (Klein and Waterhouse, 2000). This insect has been recognized since the 1970 s as a potential 
pest of fruit crops (González et al., 1973) but has attracted wider attention only recently due to its quarantine status and increasing severity of infestations (González, 2003).

Two compounds that are produced by females in the abdominal tissue were identified in the late 1970 s as $(E)$-11-tetradecenyl acetate (E1114:OAc) and (E)-11-tetradecenol (E11-14:OH), and a mixture of these compounds is attractive to males in the field (Faccin, 1979). In this study, the author proposed a 7:3 ratio for the optimal attraction of males. The bait that is most widely used to monitor P. auraria in Chile is, however, a lure that has been commercialized in other parts of the world to monitor the tufted apple bud moth (TBM) Platynota idaeusalis (Walker) (Lepidoptera: Tortricidae) (González, 2003; Ripa and Larral, 2008), a species that is not present in Chile. This lure contains $10 \mathrm{mg}$ of a 1:1 mixture of the above mentioned compounds. Preliminary experiments carried out by our group in 2011 suggested that a 1:1 mixture of E11-14:OAc and E11-14:OH is not optimal for attracting males of $P$. auraria. Additionally, Gonzalez (2003) referred to the pheromone of $P$. auraria as being a mixture of aldehyde (not acetate) and alcohol, adding some confusion as to the composition of the pheromone. Finally, accurate and easily accessible information about the pheromone of $P$. auraria may be of interest outside Chile as well, as many countries are destinations for Chilean fruit exports and are thus prone to potential invasion of Proeulia spp. For example, in 2001, a survey program for the detection of exotic pests in Western Washington in the US was carried out using a lure containing the single compound E11-14:OH to detect Proeulia spp., but not surprisingly, no moths were caught with this lure (LaGasa et al., 2001). The use of E11-14:OH, which is not attractive on its own, was most likely based on the information that is contained in a review of tortricid pheromones, in which this compound is listed as a pheromone of $P$. auraria based on the unpublished results of the authors (Roelofs and Brown, 1982).
In summary, there is a need to clarify the composition of the pheromone of $P$. auraria; therefore, we decided to reexamine the contents of the sex pheromone gland of females of this species, leading to the identification of additional biologically active minor compounds, which paves the way for the formulation of monitoring lures with increased specificity and efficiency.

\section{Methods and materials}

Insects. Larvae of $P$. auraria were collected from an infested vineyard in central Chile ( $34^{\circ} 40^{\prime} \mathrm{S}$, $\left.71^{\circ} 13^{\prime} \mathrm{W}\right)$ and transported to the laboratory, where they were kept in rearing chambers $(25$ $\pm 1^{\circ} \mathrm{C}$; $16 \mathrm{~L}: 8 \mathrm{D} ; 50 \pm 5 \%$ relative humidity) and supplied with host plant foliage (Vitis vinifera $\mathrm{L}$. leaves). The pupae were sexed, and both males and females were kept separately under natural light conditions. After adult emergence, virgin moths were kept individually and provided with a $5 \%$ sugar solution through a cotton wick.

Extraction of the glands. The activity of female $P$. auraria was observed by placing the insects individually in $150-\mathrm{mL}$ sterilized glass containers that were covered with screen and maintained under ambient conditions. Calling behavior (wing fanning, curving of the abdomen, and extrusion of the abdominal gland) was observed during the last $2 \mathrm{~h}$ of the scotophase. Virgin females (1-3 d old) were killed at that time by cooling at $-20{ }^{\circ} \mathrm{C}$ for $10 \mathrm{~min}$. The pheromone glands were extruded by gently pressing the abdominal tips, excised, and immersed in $10 \mu \mathrm{L}$ of hexane (SupraSolv, Merck, Darmstadt, Germany) that was previously cooled to $-20^{\circ} \mathrm{C}$. After $10 \mathrm{~min}$, the hexane was carefully removed. To extract the lipid fraction, $50 \mu \mathrm{L}$ of chloroform (p.a., Merck, Darmstadt, Germany) was added to the remaining gland tissue. After 2 $\mathrm{h}$, the solvent was carefully removed. The extracts were either analyzed immediately or stored at -20 ${ }^{\circ} \mathrm{C}$ until use. Batches of the extracts were prepared by pooling two or three glands. 
Chemicals. E11-14:OAc, (Z)-11-tetradecenyl acetate (Z11-14:OAc), and E11-14:OH were purchased from Bedoukian, Inc. (Danbury, USA). Tetradecanol was purchased from Sigma-Aldrich (St. Louis, USA). Tetradecyl acetate (14:OAc) was obtained with a purity of $>99 \%$ (GC) by acetylation $\left(\mathrm{Ac}_{2} \mathrm{O}\right.$, pyridine, DMAP) of tetradecanol and purified by column chromatography on silica gel. Impurities including the respective geometrical isomers in E11-14:OAc and Z11-14:OAc were removed by column chromatography on silica gel that was impregnated with silver nitrate as previously described (Reyes-García et al., 2011), leading to purities of $>99 \%$ (GC). Preparation of methyl $(E)$ - and (Z)-11-tetradecenoate: (Z)-11-tetradecenol (Z11-14:OH) was obtained by reducing $\left(\mathrm{LiAlH}_{4}\right.$, THF) Z11-14:OAc. In separate reactions, E11-14:OH and Z11-14:OH were oxidized to the corresponding acids (Jones reagent, acetone), which were subsequently transformed to the respective methyl esters by treatment with $\mathrm{BF}_{3}$-methanol. Other fatty acid methyl ester (FAME) reference compounds were purchased from Supelco (37 component FAME Mix, catalog \#47885-U). The other reagents were purchased from Sigma-Aldrich or Merck at the highest available purity and used as received.

Chemical analysis. Gas chromatographic analyses were carried out using a Shimadzu GC-2010 Plus (Shimadzu, Kyoto, Japan) gas chromatograph that was equipped with a flame ionization detector (FID) and either a fused silica RTX-5 capillary column $(30 \mathrm{~m} \times 0.25 \mathrm{~mm}$ id, $0.25 \mu \mathrm{m}$ film, Restek, Bellefonte, PA, USA), a fused silica RTX-Wax capillary column $(30 \mathrm{~m} \times 0.32 \mathrm{~mm}$ id, $0.25 \mu \mathrm{m}$ film, Restek), or a SP-2380 capillary column (30 $\mathrm{m} \times 0.25 \mathrm{~mm}$ id, $0.25 \mu \mathrm{m}$ film, Supelco, Bellefont, PA, USA). For the RTX-5 column, the oven was programmed from $50{ }^{\circ} \mathrm{C}$ for $5 \mathrm{~min}$ to $270{ }^{\circ} \mathrm{C}$ at $8{ }^{\circ} \mathrm{C} \mathrm{min}^{-1}$; for the RTX-Wax column, the conditions were $50{ }^{\circ} \mathrm{C}, 2$-min hold, $10{ }^{\circ} \mathrm{C} \mathrm{min}-1$ to 220 ${ }^{\circ} \mathrm{C}$; and for the SP-2380 column, the conditions were $50{ }^{\circ} \mathrm{C}, 5$-min hold, $7^{\circ} \mathrm{C} \mathrm{min}{ }^{-1}$ to $230^{\circ} \mathrm{C}$. The GC was operated in split/splitless mode (30-s sampling time) with an injector temperature of $250^{\circ} \mathrm{C}$, and helium was used as the carrier gas.
For GC with electroantennographic detection (GC-EAD), a Shimadzu GC-2014 AFSC gas chromatograph that was coupled to an electroantennographic detector (Syntech, Kirchzarten, Germany) was used. The GC columns and conditions were the same as described above. The column effluent was split in two equal parts, with one part going to the FID and the other through a heated transfer line into a humidified airstream $\left(400 \mathrm{~mL} \mathrm{~min}^{-1}\right)$ that was directed to the antennal preparation. The antennae were prepared by decapitating the insect and connecting the base of the head to one electrode and the tips of both of the antennae to the other electrode (Syntech probe); the electrodes were previously covered with conducting gel. The signal was acquired with the signal acquisition interface IDAC-2 (Syntech) and recorded and processed using the software GC-EAD 2010 v1.2.2 (Syntech).

GC-MS analyses were carried out using a Shimadzu GCMS-QP2010 Ultra combination using the same GC columns and conditions as above. Electron impact mass spectra were acquired at $70 \mathrm{eV}$.

Derivatization. A hexane gland extract containing one female equivalent was derivatized with dimethyldisulfide (DMDS) (Buser et al., 1983). The derivatized extract was analyzed by GC-MS using the RTX-5 column as described above.

The transesterification of the chloroform gland extract was carried out by adding $50 \mu \mathrm{L}$ of $20 \%$ boron trifluoride-methanol reagent to $50 \mu \mathrm{L}$ of the extract containing 3 female equivalents in a gas-tight vial and maintaining the mixture at 60 ${ }^{\circ} \mathrm{C}$ for $2 \mathrm{~h}$. After cooling to room temperature, water and hexane were added. The organic phase was carefully separated, dried $\left(\mathrm{Na}_{2} \mathrm{SO}_{4}\right)$, and analyzed by GC/MS using the SP-2380 column as described above.

Field experiments. Field tests with synthetic compounds were carried out in an organically managed vineyard ( $V$. vinifera) near Nancagua $\left(34^{\circ} 40^{\prime} \mathrm{S}, 71^{\circ} 13^{\prime} \mathrm{W}\right)$ and in an organically man- 
aged apple orchard (Malus domestica Borkh.) near San Fernando (34 35' S, 70 $59^{\prime}$ W). Blends of synthetic compounds were prepared in hexane and white rubber septa (Sigma-Aldrich, St. Louis, MO, USA, catalog \#Z553905) that were loaded with $100 \mu \mathrm{L}$ of the respective solutions. Septa were placed inside Delta traps (Pherocon II B, Trécé Inc., USA). Septa that were treated with only $100 \mu \mathrm{L}$ of hexane were used as controls. The traps were placed at 1.0 to $1.5 \mathrm{~m}$ height with a distance of 30 to $35 \mathrm{~m}$ between the traps. A completely randomized block design was used in first and fourth experiments, and a completely randomized design in second and third field experiments. The captured males were counted once a week. Cumulative $P$. auraria male captures were analyzed by a 2-way and 1-way ANOVA test, respectively, followed by Tukey's test $(\mathrm{P} \leq 0.05)$ using Minitab 16.

The first field trial was conducted from February 3 to 23, 2012, in Nancagua. In this experiment, the attractiveness of pure E11-14:OAc, E11-14:OH, and a 1:1 mixture of both compounds were evaluated, applying doses of $0.01,0.1,1$, and $10 \mathrm{mg}$. Four replicates per treatment were used.

The second field test was conducted from February 27 to March 5, 2013, in San Fernando. In this experiment, the different possible binary, ternary, and quaternary mixtures of the EADactive compounds were evaluated at a $500-\mu \mathrm{g}$ dose of the main component. Three replicates per treatment were used.

The third field experiment was conducted from March 22 to 26, 2013, in San Fernando and was designed based on the finding that the addition of $1 \%$ Z11-14:OAc enhanced the trap catches, while the addition of $4 \%$ resulted in lower captures. The three possible ternary mixtures with $1 \%$ Z11-14:OAc and two quaternary mixtures with $1 \%$ and $4 \% \mathrm{Z11}-14: \mathrm{OAc}$, respectively, were tested at a dose of $500 \mu \mathrm{g}$ of the main compound. Three replicates per treatment were used.
The fourth experiment was carried out from October 22 to 28, 2013, in Nancagua, used a lower dose of the main component $(100 \mu \mathrm{g})$, and compared directly different 3- and 4-component blends with the 1:1 mixture of E11-14:OAc and E11-14:OH. Three replicates per treatment were used.

\section{Results}

GC-EAD analyses of the hexane extracts of pheromone glands of virgin females using male antennae reproducibly revealed the presence of three EAD-active compounds (Figure 1), while in some runs, the antennae also responded to a fourth compound.

The mass spectrum of compound 1 showed the fragment ions $m / z 43,61,168$, and 196, and the retention indices on both of the columns (1811 on RTX-5 and 2090 on RTX-Wax) coincided with those of synthetic 14:OAc. Compounds 2 and 3 had fragments $m / z 43,61$, and 194, suggesting that these compounds are tetradecenyl acetates. The mass spectra of the DMDS adducts of both of the compounds showed the molecular ion $\mathrm{m} / \mathrm{z}$ 348 and the diagnostic fragments $m / z 89$ and 259, indicating a double bond at position 11 in the underivatized molecules. The retention indices of compound 2 (1807 on RTX-5 and 2134 on RTXWax) and compound 3 (1808 on RTX-5 and 2144 on RTX-Wax) coincided with those of synthetic E11-14:OAc and Z11-14:OAc, respectively. The mass spectrum of compound $4(\mathrm{~m} / \mathrm{z} 41,194$, and 212) and its DMDS adduct $(\mathrm{m} / \mathrm{z} 89,217$, and 306) suggested an 11-tetradecenol, and the retention indices on both columns (1675 on RTX-5, 2215 on RTX-Wax) were identical to those of synthetic E11-14:OH. The amounts of the minor compounds relative to the main compound E11-14:OAc (set to 100$)$ were $11.0 \pm 2.6$ (14:OAc), $4.1 \pm 1.1$ (Z1114:OAc), and $37.0 \pm 19.7(\mathrm{E} 11-14: \mathrm{OH})(\mathrm{n}=5)$. Other structurally related non-EAD-active minor compounds were identified as tetradecanol and (Z)-11-tetradecenol (data not shown). 


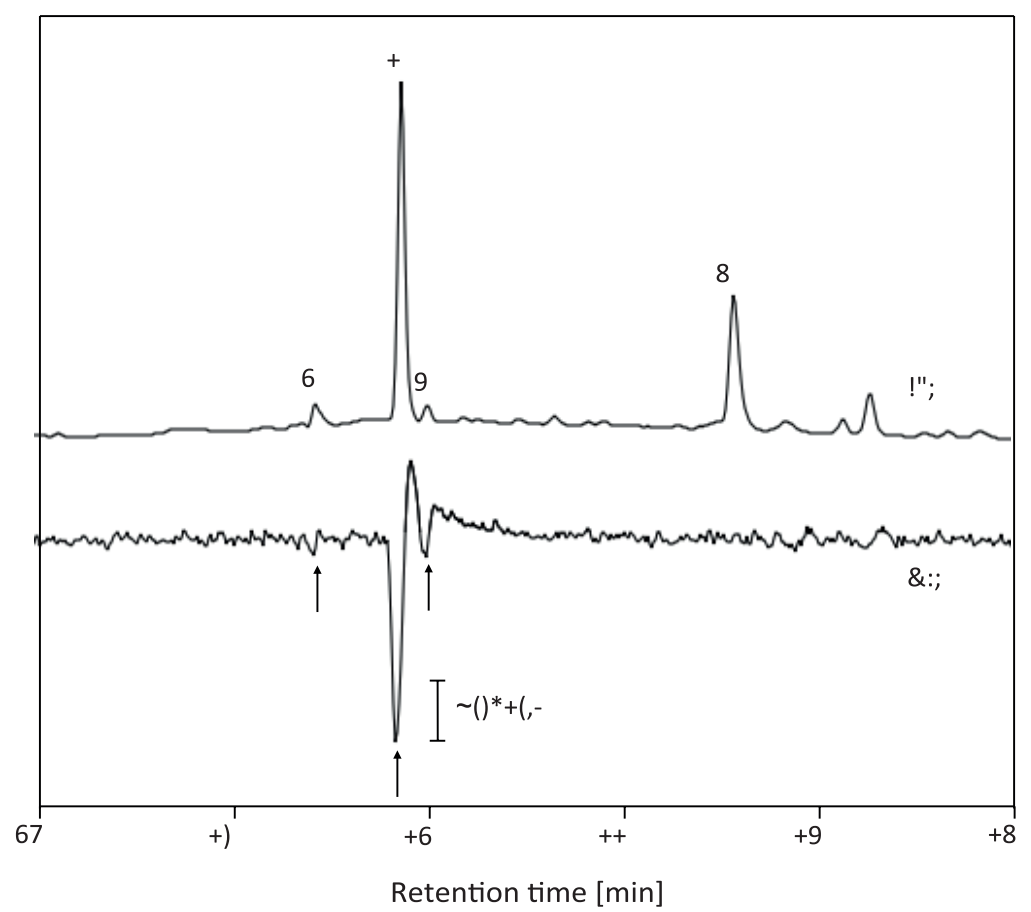

Figure 1. Gas chromatogram (RTX-Wax column) of an extract of the abdominal glands of female Proeulia auraria with simultaneous detection by FID (upper trace) and EAD (lower trace). The arrows indicate the EAD responses.

A first field experiment that was carried out with the two known compounds from the literature showed that E11-14:OAc alone was attractive to $P$. auraria males, while E11-14:OH was not attractive on its own and had no synergistic effect when added to E11-14:OAc (Figure 2). At a low dose $(0.01 \mathrm{mg})$, a mixture of the two compounds in 1:1 ratio was as attractive as the acetate alone, while at higher doses $(0.1,1$ and $10 \mathrm{mg})$, the mixture appeared much less attractive than the acetate alone, but this difference was not statistically significant. A second field experiment in which different combinations and ratios of the EADactive compounds were evaluated was carried out in a highly infested orchard and showed that all of the compounds are behaviorally active (Figure $3 \mathrm{~A})$. In this experiment, the addition of $1 \%$ of the geometrical isomer Z11-14:OAc to the main compound E11-14:OAc enhanced the trap catches, but adding $4 \%$ resulted in the complete loss of attractiveness. Binary mixtures of E11-14:OAc with 14:OAc or E11-14:OH and a ternary mixture of both minor compounds with the main compound were more attractive than E11-14:OAc alone. The addition of $4 \% \mathrm{Z} 11-14: \mathrm{OAc}$ to the binary mixtures of E11-14:OAc with 14:OAc or E11-14:OH resulted in a reduction of attraction. In this experiment, the 4-component mixture with 4\% Z11-14:OAc was attractive to males. In view of this result and to further examine the role of Z11-14:OAc, a third field experiment was carried out. The results showed that a 4-component mixture containing $1 \% \mathrm{Z} 11-14: \mathrm{OAc}$ (relative to the main compound) was the most attractive treatment, whereas the blend with 4\% Z11-14:OAc did not differ from the control (Figure $3 \mathrm{~B}$ ). The 3-component blends were less attractive than the 4-component mixture with 1\% Z11-14:OAc. The results of the fourth field experiment confirmed the previous results, although, due to a high variance, not all of the differences were statistically significant (Figure $3 \mathrm{C})$. However, the 4-component blend was significantly more attractive than the 2-component mixture that is actually in use. 


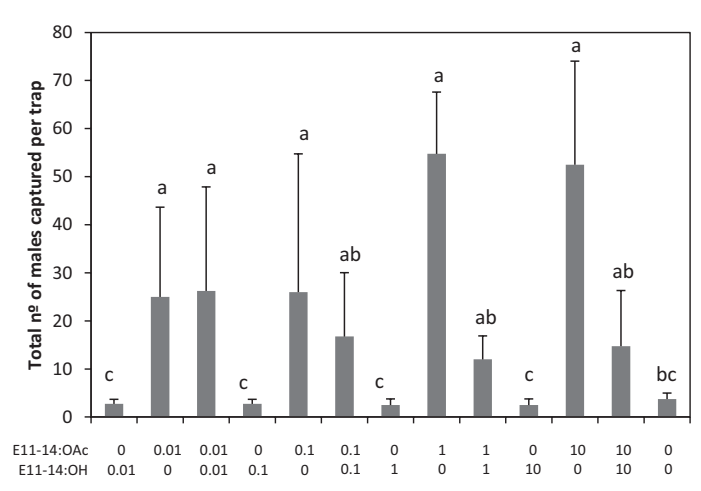

Figure 2. Attraction of Proeulia auraria males to lures that were loaded with different doses and blends of pheromone compounds $(n=4)$. The experiment was conducted from February 3 to 23, 2012, in a grapevine field near Nancagua in central Chile. The treatments with different letters are significantly different according to an ANOVA followed by Tukey's test $(\mathrm{P} \leq 0.05)$.

The GC/MS analysis of the transesterified chloroform gland extract on the SP-2380 column revealed the presence of two methyl tetradecenoates $(\mathrm{m} / \mathrm{z} 55,74,87,166$, and 208$)$ that were identified as methyl myristoleate (Z9-14:COOMe) and methyl (E)-11-tetradecenoate (E11-14:COOMe), respectively, by comparing their mass spectra and retention times with those of authentic reference compounds. No clear evidence for the presence of methyl (Z)-11-tetradecenoate (Z11-14:COOMe) could be found (Figure 4). Other methyl esters that were present in the derivatized extract included palmitate and oleate (most abundant), palmitoleate, stearate, linoleate, and $\gamma$-linolenate (abundant) and other even- and odd-numbered straight chain saturated and unsaturated esters (less abundant).

\section{Discussion}

The genus Proeulia is almost exclusively from Chile and represents the most diverse genus within the family Tortricidae in this country (Razowski and Pelz, 2010). Proeulia belongs to the tribe Euliini (subfamily Tortricinae) (Gilligan et al., 2012), which is distributed mostly in the Neotropical region. The only pheromone that has been identified to date from a species of this tribe is that of Bonagota cranaodes (Meyrick), native to South America, which consists of
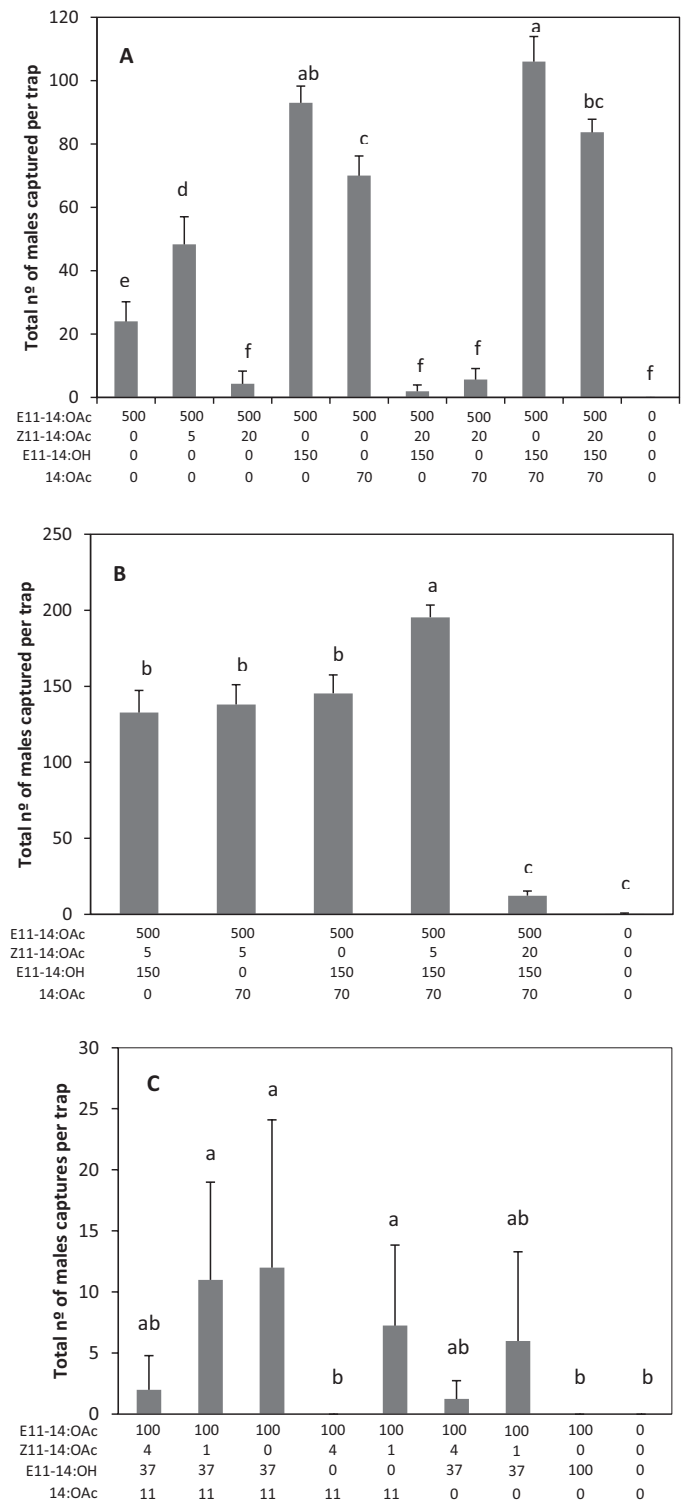

Figure 3. Attraction of Proeulia auraria males to lures that were loaded with different blends of pheromone compounds $(n=3)$. A. The experiment was conducted from February 27 to March 5, 2013, in an apple orchard near San Fernando in central Chile. B. The experiment was conducted from March 22 to 26, 2013, in an apple orchard near San Fernando in central Chile. C. The experiment was conducted from October 22 to 28, 2013, in a grapevine field near Nancagua in central Chile. The treatments with different letters are significantly different according to an ANOVA followed by Tukey's test $(\mathrm{P} \leq$ $0.05)$. For the experiment shown in $\mathrm{C}$ the Analysis was performed on the $\log (\mathrm{x}+1)$ transformed data.

an unusual four-component blend containing E3,Z5-12:OAc, Z5-12:OAc, E3,Z5-14:OAc, and Z9-16:OAc (Unelius et al., 1996; Eiras et al., 


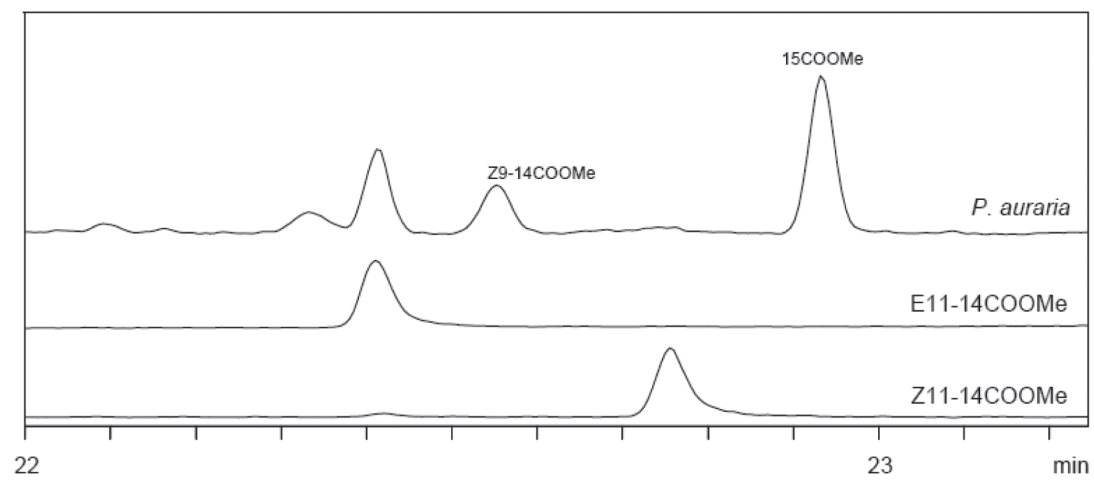

Figure 4. Mass chromatogram $\left(\mathrm{m} / \mathrm{z} 55\right.$, base peak of $\Delta 1-14$ :COOMe) of a derivatized $\left(\mathrm{BF}_{3}-\right.$ $\mathrm{MeOH}$ ) chloroform extract of the pheromone gland of $P$. auraria.

1999; Coracini et al, 2001). Males of a Holarctic species, Eulia ministrana L., are attracted to a mixture of Z11-14:OAc and Z9-14:OAc (Booij and Voerman, 1984; Priesner, 1984). Compounds with a chain length of 14 carbon atoms and a double bond in position 11, as found in P. auraria, have been identified from at least 66 Tortricinae species, which is most likely the most common type of pheromone compound in this subfamily (Ando et al., 2004).

When several species share pheromone components, a delicate fine-tuning of the complete blend is necessary to secure the privacy of the communication channels among sympatric and synchronic species (Cardé et al., 1977). In our experiments, $P$. auraria males appeared to be very sensitive to the relative abundance of the geometric isomer of the main compound. The presence of $1 \%$ Z11-14:OAc enhanced the trap catches, while the addition of 4\% Z11-14:OAc strongly reduced attraction. Intriguingly, the mean E/Z ratio in the gland extracts was 100:4, and the ratios in the individual extracts (consisting each of 2-3 glands) ranged from 100:2.5 to 100:5.2. The ratio that is actually released by the females, however, has not been determined. The composition of compounds in the female gland (liquid phase) does not necessarily correspond to the composition after release from the gland (vapor phase) due to different vapor pressures; however, the differences in the vapor pressures of geometrical isomers are rather small, so that the differences in their ratio in the liquid and vapor phase, respectively, should be rather small as well (Olsson et al., 1983). In addition, so called "anomalous results", i.e., male moths that are not attracted by the ratio of pheromone compounds that is produced by females, have been previously identified and prompted Roelofs (1978) to propose a threshold hypothesis for pheromone perception. In a diagram plotting binary pheromone component ratios vs. release rate (or concentration), lower and upper threshold lines for flight activation and disorientation, respectively, define an "attraction area" between these threshold lines over the full range of mixtures. The natural blend or unnatural blends may or may not fall into the attraction area, depending on their concentration. The results of our first field experiment (Figure 2) indicate that the response of males to a given mixture of compounds (in this case, the off-blend 1:1 mixture of E1114:OAc and E11-14:OH) relative to the response to the single main pheromone component is concentration-dependent. Experiments with the spruce seed moth Cydia strobilella (Tortricidae) showed that optimal blends of the two isomers composing the pheromone are attractive only at low concentrations, whereas various off-blends are attractive at higher doses, in agreement with the threshold hypothesis (Wang et al., 2010). 
The $\Delta 11$ double bond in moth pheromone components is usually introduced by the action of a $\Delta 11$ desaturase (Bjostad et al., 1987; Lienard et al., 2008 and references therein). In many studied species, the desaturase produces a mixture of the $(E)$ - and $(Z)$-11-tetradecenoate pheromone precursor both in vivo and upon expression in heterologous systems. The exact ratio between the pheromone components is subsequently determined by the selectivity of the fatty acyl reductases that are involved in the production of the corresponding alcohols from the acyl precursors (Lassance et al., 2010, 2013). What is the mechanism behind the production of the strongly E-biased pheromone in $P$. auraria? The fact that the analysis of fatty acyl moieties in the pheromone gland revealed large amounts of $(E)$-11-tetradecenoate but no clear trace of $(Z)$ 11-tetradecenoate suggests that the specificity of the desaturase is important for the production of the strongly E-biased pheromone. A $\Delta 11$ desaturase producing only the $\mathrm{E}$ isomer has previously been reported from the tortricid moths Choristoneura parallela (Liu et al., 2004) and Epiphyas postvittana (Liu et al., 2002).

With respect to the complete blend that is released by female $P$. auraria, our results indicate that the three minor compounds are important in enhancing the sensitivity of conspecific males toward the blend. In addition, it is possible that these compounds provide additional information to the males of other species to recognize the blend as heterospecific (Linn et al., 1988; Linn and Roelofs, 1989). In this context, it will be interesting to study the sex pheromones of other syntopic (i.e., sympatric occupying the same macrohabitat) and synchronic species closely related to $P$. auraria, for example, $P$. chrysopteris (Butler) and P. triquetra (Obraztsov), which share some tree fruit hosts in Chile. No individuals of the latter two species have been captured in the traps, and it seems plausible that the specificity of the respective sex pheromones might be the key mechanism to reproductive isolation between these species (Roelofs and Brown, 1982).
For practical applications, our results demonstrate that the lure that is currently used to monitor $P$. auraria in Chile is not optimal in terms of dose and composition. In our experiments, the most attractive blend consisted of E11-14:OAc, Z11-14:OAc, E11-14:OH, and 14:OAc in a 100:1:30:14 ratio. The results that were obtained in the field experiments (e.g., the synergistic effect of the minor compounds) and the considerations in the context of the threshold hypothesis suggest that it might be possible to use a lower dose of the 4-component blend to monitor the flight of $P$. auraria compared to the dose of the lure that is currently in use with the consequent economic benefit. Studies regarding the longevity and specificity of lures to develop the optimal lure are underway. Furthermore, our results show that for the preparation of lures, it is critical to know the stereoisomerical purity of E11-14:OAc from commercial sources, as the presence of only $4 \%$ of the stereoisomer reduced the attraction at the tested doses, whereas a lower amount of the $\mathrm{Z}$ isomer had a synergistic effect.

In summary, our reinvestigation of the pheromone of $P$. auraria resulted in a multicomponent pheromone with superior activity compared to the previously used 2-component attractant. The discrepancy between the ratios of the minor components in pheromone gland extracts and the optimal ratio for the attraction of males in the field is intriguing, but we still believe that our study represents a significant step forward towards an optimized pheromone for an important pest in Chilean fruit orchards.

\section{Acknowledgements}

The authors thank Dr. M. Fernanda Flores and M. Soledad Oyarzún for help with the field experiments. JB thanks the Fondo Nacional de Desarrollo Científico y Tecnológico (FONDECYT grant $n^{\circ} 1110365$ ) and the Deutscher Akademischer Austauschdienst (DAAD) for financial support. LR thanks MECESUP (project UCH 0601) for a doctoral fellowship. 


\section{Resumen}

L. Reyes-Garcia, Y. Cuevas, C. Ballesteros, T. Curkovic, C. Löfstedt y J. Bergmann. 2014. Una feromona de cuatro componentes del enrollador de los frutales Proeulia auraria (Lepidoptera: Tortricidae). Cien. Inv. Agr. 41(2):187-196. El enrollador de los frutales, Proeulia auraria es una plaga de frutales de importancia económica. Los compuestos acetato de (E)-11-tetradecenilo (E11-14:OAc) y (E)-11-tetradecenol (E11-14:OH) habían sido determinados como atrayentes a machos de P. auraria, los cuales actualmente están siendo usados en Chile para el monitoreo de esta especie. Experimentos preliminares realizados por nuestro grupo de investigación indicaron que la mezcla de estos dos compuestos no es óptima para atraer machos, lo que nos llevó a reinvestigar los componentes de la feromona sexual de P. auraria. Los compuestos fueron extraídos desde la glándula feromonal con hexano, y fueron identificados usando cromatografía de gases con detección electroantenográfica (GC-EAD), cromatografía de gases-espectrometría de masas (GC-MS) y comparación de los datos analíticos de los compuestos naturales con los de compuestos auténticos de referencia. Los compuestos activos en EAD fueron identificados como acetato de tetradecilo (14:OAc), E11-14:OAc, acetato de (Z)-11-tetradecenilo (Z11-14:OAc) y E11-14:OH, en la razón relativa de 11:100:4:37. Ensayos en condiciones de campo mostraron que los cuatro compuestos identificados son activos sobre el comportamiento de los machos. La mezcla más atrayente y a la vez más atractiva que la mezcla de dos compuestos actualmente en uso, contenía el compuesto principal E11-14:OAc, 1\% del isómero geométrico Z11-14:OAc y ambos de los otros compuestos menores. Aumentar el porcentaje de Z11-14:OAc al $4 \%$ resultó en una reducción significativa de atracción de machos. Un análisis del contenido de ácidos grasos de la glándula feromonal mostró la presencia de $(E)$-11-tetradecenoato, pero no de (Z)-11-tetradecenoato. Se discute el posible rol de esta feromona fuertemente sesgada hacia el isómero E en la separación de especies y su posible origen biosintético.

Palabras clave: Eulia, Euliini, especies nativas, atrayente sexual, Tortricinae.

\section{References}

Ando,T., S. Inomata, and M. Yamamoto. 2004. Lepidopteran sex pheromones. Top. Curr. Chem. 239:51-96.

Booij, C.J.H., and S. Voerman. 1984. New sex attractants for 35 tortricid and 4 other lepidopterous species, found by systematic field screening in the Netherlands. J. Chem. Ecol. 10:135-144.

Bjostad, L.B., W. Wolf., and W.L. Roelofs. 1987. Pheromone biosynthesis in lepidopterans: Desaturation and chain shortening. In: Blomquist, G.J. and G.D. Prestwich (eds.). Pheromone Biochemistry, Academic Press, Orlando, Florida. p. 77-120.

Buser, H.-R., H. Arn, P. Guerin, and S. Rauscher. 1983. Determination of double bond position in mono-unsaturated acetates by mass spectrometry of dimethyl disulfide adducts. Anal. Chem. $55: 818-822$.
Cardé, R.T., A.M. Cardé, A.S. Hill, and W.L. Roelofs. 1977. Sex attractant specificity as a reproductive isolating mechanism among the sibling species Archips argyrospilus and mortuans and other sympatric tortricine moths (Lepidoptera: Tortricidae). J. Chem. Ecol. 3:71-84.

Coracini, M.D.A., M. Bengtsson, A. Reckziegel, J. Löfqvist, W. Francke, E.F. Vilela, A.E. Eiras, A. Kovaleski, and P. Witzgall. 2001. Identification of a four-component sex pheromone blend in Bonagota cranaodes (Lepidoptera: Tortricidae). J. Econ. Entomol. 94:911-914.

Eiras, A.E., A. Kovaleski, E.F. Vilela, J.-P. Chambon, C.R. Unelius, A.-K. Borg-Karlson, I. Liblikas, R. Mozuraitis, M. Bengtsson, and P. Witzgall. 1999. Sex pheromone of the Brazilian Apple leafroller, Bonagota cranaodes Meyrick (Lepidoptera: Tortricidae). Z. Naturforsch. 54c:595-601. 
Faccin, M. 1979. Feromona sexual del enrollador de la vid Proeulia auraria (Clarke) (Lepidoptera: Tortricidae). Thesis, Universidad de Chile, Santiago, Chile. 64 pp.

Gilligan, T. M., J. Baixeras, J. W. Brown, and K. R.Tuck. 2012. T@RTS: Online World Catalogue of the Tortricidae (Ver. 2.0). Available online at: $<$ http://www.tortricid.net/catalogue.asp $>$ (Website accessed: December 23, 2013).

González, R.H., P. Arretz, and L. Campos. 1973. Catálogo de las Plagas Agrícolas de Chile. Universidad de Chile, Publicaciones Ciencias Agrícolas N’2. Santiago, Chile. 68 pp.

González, R.H. 2003. Las polillas de la fruta en Chile. Universidad de Chile, Serie Ciencias Agronómicas No 9. Santiago, Chile. 188 pp.

Klein, C. and D. F. Waterhouse. 2000. Distribution and importance of arthropods associated with agriculture in Chile. Australian Centre for Intl. Agr. Res Monograph No. 68. 231 pp.

LaGasa, E.H., P. Hertzog, D. Barshis, K. Turner, and H. Smith. 2001. 2001 Western Washington Exotic Pest Detection Survey; A Pheromone-trap Survey for Proeulia spp. (Lepidoptera: Tortricidae). 2001 Entomology Project Report - WSDA PUB 063.

Lassance, J.-M., A.T. Groot, M.A. Liénard, B. Antony, C. Borgwadt, F. Andersson, E. Hedenström, D.G. Heckel, and C. Löfstedt. 2010. Allelic variation in a fatty-acyl reductase gene causes divergence in moth sex pheromones. Nature 466:486-489.

Lassance, J.-M., M.A. Liénard, B. Antony, S. Qian, T. Fujii, J. Tabata, Y. Ishikawa, and C. Löfstedt. 2013. Functional consequences of sequence variation in the pheromone biosynthetic gene pgFAR for Ostrinia moths. Proc. Natl. Acad. Sci. USA 110:3967-3972.

Liénard, M.A., M. Strandh, E. Hedenström, T. Johansson, and C. Löfstedt. 2008. Key biosynthetic gene subfamily recruited for pheromone production prior to the extensive radiation of Lepidoptera. BMC Evol. Biol. 8:270:1-15.

Linn Jr., C.E., and W.L. Roelofs. 1989. Response specificity of male moths to multicomponent pheromones. Chem. Senses 14:421-437.

Linn Jr., C.E., A. Hammond, J. Du, and W.L. Roelofs. 1988. Specificity of male response to multicomponent pheromones in noctuid moths Trichoplusia ni and Pseudoplusia includens. J. Chem. Ecol. 14:47-57.

Liu, W., H. Jiao, N.C. Murray, M. O'Connor, and W.L. Roelofs. 2002. Gene characterized for membrane desaturase that produces $(E)-11$ isomers of mono- and diunsaturated fatty acids. Proc. Natl. Acad. Sci. USA 99:620-624.

Liu, W.-T., A.P. Rooney, B.-Y. Xue, and W.L. Roelofs. 2004. Desaturases from the spotted fireworm moth (Choristoneura parallela) shed light on the evolutionary origins of novel moth sex pheromone desaturases. Gene 342:303-311.

Olsson, A.-M., J.A. Jönsson, B. Thelin, and T. Liljefors. 1983. Determination of the vapor pressures of moth sex pheromone components by a gas chromatographic method. J. Chem. Ecol. 9:375-385.

Priesner, E. 1984.The pheromone receptor system of male Euliaministrana L., with notes on other Cnephasiini moths.Z. Naturforsch. C. 39:849-852.

Razowski, J. and V. Pelz. 2010. Tortricidae from Chile (Lepidoptera: Tortricidae). SHILAP Revta. Lepidop. 38:5-55.

Reyes-García, L., M.F. Flores, W. Vera, and J. Bergmann. 2011. Biological activity of the larval secretion of Chilecomadia valdiviana. J. Chem. Ecol. 37:1137-1142.

Ripa, R. and P. Larral (eds.). 2008. Manejo de plagas en paltos y cítricos. Instituto de Investigaciones Agropecuarias (INIA), Colección Libros INIA $\mathrm{N}^{\circ}$ 23. La Cruz, Chile.

Roelofs, W. L. 1978. Threshold hypothesis for pheromone perception. J. Chem. Ecol. 4:685-699.

Roelofs, W.L. and R. L. Brown. 1982. Pheromones and evolutionary relationships of Tortricidae. Ann. Rev. Ecol. Syst. 13:395-422.

Unelius, C.R., A.E. Eiras, P. Witzgall, M. Bengtsson, A.Kovaleski, E.F.Vilela, and A.-K. Borg-Karlson. 1996. Identification and synthesis of the sex pheromone of Phtheocroa cranaodes (Lepidoptera: Tortricidae). Tetrahedron Lett. 37:1505-1508.

Wang, H.-L., G.P. Svensson, O. Rosenberg, M. Bengtsson, E.V. Jirle, and C. Löfstedt. 2010. Identification of the sex pheromone of the spruce seed moth, Cydia strobilella L. (Lepidoptera: Tortricidae). J. Chem. Ecol.36:305-313. 